$\mathrm{A} \int_{\text {ass }} \mathrm{H}$

Article history :

Received : 28.01.2016

Revised : 18.04.2016

Accepted : 28.04.2016

Members of the Research Forum

Associated Authors:

${ }^{1}$ Department of Vegetable Crops,

Horticultural College and Research Institute, Tamil Nadu Agricultural

University, PERIYAKULAM (T.N.) INDIA

\footnotetext{
Author for correspondence : N. ROHINI

Department of Vegetable Crops, Horticultural College and Research Institute, Tamil Nadu Agricultural University, PERIYAKULAM (T.N.) INDIA

Email : rohizna@gmail.com
}

THEASIAN JOURNALOF HORTICULTURE

Volume 11 | Issue 1 | June, 2016 | 86-92

Visit us -www.researchjournal.co.in

\title{
Heterobeltiosis and inbreeding depression for fruit yield and its components in hot pepper (Capsicum annuum var. annuum)
}

\section{N. ROHINI AND V. LAKSHMANAN ${ }^{1}$}

ABSTRACT : A diallel study was conducted during 2012 - 13, 2013- 14 at Horticultural College and Research Institute, Periyakulam, Tamil Nadu Agricultural University, India to assess the extent of heterosis and inbreeding depression in chilli. Five crosses namely, K 1 x Arka Lohit, LCA 625 x K 1, Pusa Jwala x K 1, Pusa Jwala x PKM 1 and K 1 x PKM 1 exhibited higher percentages of heterobeltiosis, revealing involvement of non - additive genes and these crosses may be considered as the promising crosses for yield. The crosses gave higher heterobeltiosis in $F_{1}$ which showed low inbreeding depression in $F_{2}$ generation. The desirable inbreeding depression that is negative in direction was observed in K 1 x PKM 1 and K 1 x Pusa Jwala for yield and yield contributing characters. Significant and positive heterosis with low inbreeding depression for yield and yield related traits were exhibited by Pusa Jwala x PKM 1, LCA 625 x K 1 and $\mathrm{K} 1 \mathrm{x}$ Arka Lohit. The segregating materials generated in $\mathrm{F}_{2}$ generation may be utilized for the identification and selection of desirable recombinants in advanced generations in order to develop high yielding varieties with specific attributes.

KEY WORDS : Better parent heterosis, Chilli, Inbreeding, Quantitative traits, Segregating generation

HOW TO CITE THIS ARTICLE : Rohini, N. and Lakshmanan, V. (2016). Heterobeltiosis and inbreeding depression for fruit yield and its components in hot pepper (Capsicum annuum var. annuum). Asian J. Hort., 11(1) : 86-92, DOI : 10.15740/HAS/TAJH/11.1/86-92. 